УДК 336.71

Захарченко Володимир, доктор економічних наук, професор,

Вінницький національний аграрний університет, кафедра адміністративного менеджменту та альтернативних джерел енергії, м. Вінниця; ORCID ID: 0000-0003-3645-2597 e-mail: zakharchenkovn@i.ua

https://doi.org/10.29038/2786-4618-2021-01-88-97

\title{
ОСОБЛИВОСТІ СТАНОВЛЕННЯ ТА ПРОБЛЕМИ ОРГАНІЗАЦЇ̈ БАНКІВСЬКОЇ СИСТЕМИ УКРАЇНИ: МІЖНАРОДНІ ПОРІВНЯННЯ
}

Визначено роль банківської системи в розвитку економіки України. Відмічено, що процес ії формування, як і в більшості країн, був досить складним і тривалим. Розглянуто комплекс проблем організації банківської системи України. Вказано на відсутність деяких видів спеціалізованих банків, надмірну універсалізацію банківських установ та їх нераціональний регіональний розподіл. Підкреслено песпективність розвитку в Україні Інтернет-банкінгу, доцільність створення окремого банку розвитку, необхідність підвищення ефективності роботи банківських спілок, асоціацій, небанківських фінансових установ та регуляторних інституцій. Відмічено, що вирішення багатьох проблем організації банківської системи України залежатиме від того, наскільки високорганізованим елементом у ній стане Національний банк. При пошуку шляхів вирішення наявних проблем враховано зарубіжний досвід.

Ключові слова: банк (спеціалізований, універсальний), Національний банк України, небанківська фінансова установа, банківська система, організація банківської системи.

Захарченко Владимир, доктор экономических наук, профессор, Винницкий национальный аграрный университет, кафедра аграрного менеджмента и альтернативных источников энергии,

г. Винница

\section{ОСОБЕННОСТИ СТАНОВЛЕНИЯ И ПРОБЛЕМЫ ОРГАНИЗАЦИИ БАНКОВСКОЙ СИСТЕМЫ УКРАИНЫ: МЕЖДУНАРОДНЫЕ СРАВНЕНИЯ}

Определена роль банковской системы в развитии экономики Украины. Отмечено, что процесс ее формирования, как и в большинстве стран, был достаточно сложным и длительным. Рассмотрен комплекс проблем организации банковской системы Украины. Указано на отсутствие некоторых видов специализированных банков, чрезмерную универсализацию банковских учреждений и их нерациональное региональное распределение. Подчеркнуто песпективнисть развития в Украине Интернет-банкинга, целесообразность создания отдельного банка развития, необходимость повышения эффективности работы банковских союзов, ассоциаций, небанковских финансовых учреждений и регуляторных институтов. Отмечено, что решение многих проблем организации банковской системы Украины будет зависеть от того, насколько високорганизованим элементом в ней станет Национальный банк. При поиске путей решения имеющихся проблем учтен зарубежный опыт.

Ключевые слова: банк (специализированный, универсальный), Национальный банк Украины, небанковское финансовое учреждение, банковская система, организация банковской системы.

Zakharchenko Volodymyr, doctor of economics, professor,

Vinnytsia National Agrarian University, Department of Administrative Management and Alternative Energy Sources, Vinnytsia 


\section{PARTICIPATION AND CITIZENS 'PARTICIPATION IN PROVIDING EFFICIENT ACTIVITIES OF LOCAL SELF-GOVERNMENT BODIES (IN THE CONTEXT OF DECENTRALIZATION REFORM)}

It is noted that the role of the banking system in the development of Ukraine's economy is exceptional, as it has a multiplier effect on all its other components. Therefore, it is important to solve a set of problems related to its formation and modern organization.

The purpose of the article is to study the peculiarities of formation and search for ways to improve the organization of the banking system of Ukraine, taking into account foreign experience.

It is noted that the process of formation of the two-tier banking system of Ukraine, as well as most countries, was quite complex and long. In this regard, a set of problems related to its modern organization is considered, and ways to solve them in the context of foreign experience are outlined. It is shown that in the structure of the banking system of Ukraine, in contrast to Germany, Italy, USA and other countries, some types of specialized banks, in particular land and cooperative, whose services are very important for the development of small and medium business and rural areas . It is proved that the tendencies to universalization and uneven distribution by regions of banking institutions do not contribute to improving the efficiency of their operation. The prospects of Internet banking development and the expediency of establishing the Ukrainian Development Bank are emphasized. It is noted that in Ukraine, in contrast to, for example, France, banks have limited membership in various unions or associations, which does not provide a synergy effect and makes it difficult to control their activities. It is shown that banks in Ukraine are not officially members of financial-industrial groups and, unlike banks in the United States, Japan, Germany, South Korea and other countries, do not play a proper role in the development of the national economy. It is noted that non-bank financial institutions in the future may play, as the experience of the United States and the United Kingdom, a significant role in financing business development. It is shown that the role of such institutions and institutions as new legislative acts, the Deposit Guarantee Fund of individuals, the Financial Stability Board, etc. should increase in solving the problems of the organization of the banking system of Ukraine. It is noted that the solution of many problems of the organization of the banking system of Ukraine will depend on how highly organized the NBU will be in it. To do this, it is necessary to: clarify its functions (taking into account the experience of the Bank of France); bring under them a new organizational structure; intensify the work of the Monetary Policy Committee (based on the experience of the United Kingdom and Canada); clearly define reserve assets, independence and forms of interaction with the government (taking into account the experience of Japan and other countries); increase the transparency of activities.

Improving the organization of the banking system of Ukraine in accordance with international practices and European standards will help increase its efficiency and successful implementation of the tasks facing it in terms of national economic development.

Key words: bank (specialized, universal), National Bank of Ukraine, non-bank financial institution, banking system, organization of the banking system.

Постановка проблеми. В розвитку економіки України роль банківської системи $\epsilon$ дуже значимою, тому що вона справляє мультиплікативний вплив на усі інші їі складові. Вона забезпечує потреби обігу в платіжних засобах, акумулює капітал для потреб суспільного відтворення, сприяє розширенню обсягів і підвищенню ефективності суспільного виробництва, «працює» на зміцнення договірної і платіжної дисципліни суб'єктів господарювання тощо. Якщо ж банківська система належним чином не сформована i дезорганізована, то це може підсилювати кризові явища в економіці, виявлятися в падінні обсягів інвестицій та виробництва, зростанні безробіття, зниженні життєвого рівня населення тощо. Відтак, важливо вирішити комплекс проблем, пов’язаних із формуванням та організацією діяльності банківської системи України.

Аналіз останніх досліджень і публікацій. Широке коло проблем, що стосуються формування та удосконалення діяльності банківської системи України, в т. ч. із врахуванням зарубіжного досвіду, розглянули у своїх працях такі вчені, як О. Барановський та ін. [1], О. Горох [2], К. Далгич [3], О. Дзюблюк [4], Ю. Кашпрук [5], Н. Побережна та А. Колесніченко [6], С. Фімяр [7] та ін. Однак проблема удосконалення організації банківської системи України потребує спеціального i поглибленого вивчення.

Мета статті - дослідження особливостей формування та пошук шляхів удосконалення організації банківської системи України із врахуванням зарубіжного досаіду, що сприятиме підвищенню іiі стійкості та ефективності діяльності в рамках національної економіки. 
Викладення основного матеріалу. У більшості країн світу процес формування банківської системи має тривалу історію. Ї̈̈ ядро спочатку складали державні скарбниці, пізніше - центральні банки, які часто утворювалися на базі комерційних. Так, перший центральний банк у світі (Ріксбанк) було засновано у Швеції ще в 1668 р. У Великій Британії Англійський банк було перетворено на центральний та наділено його відповідними функціями тільки у 1844 р. У США було декілька періодів формування банку з функціями центрального: у 1793-1811 pp. - Першого банку США, у 1816-1913 рр. - Другого банку США, а з 1913 р. - Федеральної резервної системи (ФРС).

Банківська система України почала формуватися ще в часи Української Народної Республіки, а iii центральний банк був створений в період Гетьманату. Однак після поразки національновизвольного руху на території України та загарбання більшої ії частини радянською Росією, а 3 1922 р. - СРСР, цей процес був призупинений. Він відновився тільки у 1991 р., після того як Україна вступила в активну фазу боротьби за відновлення незалежності. Правовою підставою для цього став Закон «Про банки і банківську діяльність», ухвалений Верховною Радою України 20 березня 1991 p. Цим документом було дано старт створенню дворівневої банківської системи України ринкового типу. Верхній ii рівень склав Національний банк України (НБУ), що був створений на базі Української республіканської контори Держбанку СРСР, а нижній рівень - універсальні та спеціалізовані банки (інвестиційні, ощадні, іпотечні, споживчого кредиту, галузеві, кооперативні, внутрішньовиробничі) й небанківські фінансові установи (інвестиційні компанії, інвестиційні фонди, страхові компанії, пенсійні фонди, ломбарди, трастові компаніï), що стали масово створюватися в умовах ринкових трансформацій.

Формування двохрівневої банківської системи було цілком виправданим, тому що основною метою діяльності НБУ як центрального (емісійного) банку є підтримання в країні цінової та фінансової стабільності, тоді як комерційних банків - отримання прибутку.

До нинішнього часу банківська система України сформувалася як доволі розгалужена мережа банківських установ, проте в ній недостатньо або й зовсім не представлені деякі види спеціалізованих банків, зокрема земельні та кооперативні. У зв'язку з цим зауважимо, що створення останніх (і місцевих, i центрального) передбачено статтею 8 Закону України «Про банки і банківську діяльність». До речі, такі банки набули широкого поширення в Німеччині, Італії, США, Франції, Великій Британії, Польщі та деяких інших країнах. Вони спеціалізуються на обслугованні суб'єктів малого i середнього бізнесу (МСБ) переважно у невеликих містах та селах. Створення кооперативних а також земельних банків в Україні дозволило б вирішити проблеми фінансовокредитного обслуговування МСБ і населення в сільській місцевості та сприяло б реалізації земельної реформи в інтересах селян, а не латифундистів.

Варто ще зауважити, що сектор малих й середніх банків в Україні характеризується загальною тенденцією до універсалізації його установ, тобто надання максимально можливого спектру банківських послуг. Однак це не відповідає критеріям підвищення ефективності та фінансової безпеки їх функціонування. Згідно досліджень, проведених фахівіцями Лондонської бізнес-школи Інституту технологій НьюДжерсі та бізнес-школи Штерна при Нью-Йоркському університеті на прикладі 105 італійських банків, підвищенню їх дохідності та зменшенню фінансових ризиків більше сприяла б галузева спеціалізація та географічна диверсифікація [3, с. 160].

Крім того, в територіальній організації банківської системи України спостерігаються суттєві диспропорції. Так, станом на 01.01.2021 р. найбільше банків було зареєстровано у м. Києві - 61 банк (74\%), серед інших регіонів найбільше їх мають Дніпропетровська (5 банків), Львівська (5 банків) та Одеська (3 банки) області. Щодо кількісті структурних підрозділів банків у розрахунку на 100 тис. осіб наявного населення, яка багато в чому характеризує доступність банківських послуг, то станом на той же час в середньому по Україні на вказану кількість населення припадало 17 підрозділів в порівнянні з 24 підрозділами станом на 01.01.2016 р. Це вказує на загальну тенденцію до скорочення кількості підрозділів банків загалом і у всіх регіонах, зокрема. Особливо небажаною ця тенденція $\epsilon$ для Луганської та Донецької областей, де цей показник найменший - відповідно 5 та 8 (рис. 1).

Найбільш інноваційно орієнтованою тенденцією в організації банківських систем багатьох країн, в т. ч. й України, є перехід від класичної філіальної моделі обслуговування клієнтів до моделі дистанційного обслуговування. Ця модель (Інтернет-банкінгу) не передбачає візит клієнта в банк. 
Отже, Інтернет-банки (онлайн-банки, необанки) - це банки без відділень, і це дозволяє їм мати значну економію, порівняно 3 класичними банками, витрат на інфраструктуру (відділення, банкомати, інкасацію тощо). Відповідно, вони має можливість пропонувати клієнтам більш вигідні тарифи на послуги, ніж класичні банки [8, с. 50]. В Україні «піонерами» Інтернет-банкінгу стали «Monobank» та Приватбанк зі своїм Інтернет-банком Приват-24. Але й інші банки поступово переходять на технології дистаенційного обслуговування клієнтів.

В структурі банківської системи України все ще немає окремого банку розвитку, хоча окремі автори, зокрема Ю. Кіндзерський [9], і довели доцільність його створення для кредитування пріоритетних інвестиційних проектів, зокрема в рамках неоіндустріалізації країни. Створений ще в 2004 р. Український банк реконструкції і розвитку (що з 2017 р. на $100 \%$ має китайський капітал) не можна вважати банком розвитку (таким він $є$ тільки за назвою), тому що його участь у кредитуванні інноваційно-інвестиційних проектів $є$ мізерною.

У більшості розвинених країн, на відміну від України, банки можуть чи мають входити до складу різних спілок або асоціацій, що 3 великою ймовірністю дає синергічний ефект (від кооперативної взаємодії). Наприклад, у Франції банки в обов'язковому порядку мають бути членами асоціацій. Ця норма введена ще й для того, щоб спростити державний нагляд за банківською діяльністю. У Німеччині банки для представлення своїх інтересів у відносинах із законодавчим органом, із центральним банком, із контролюючими державними органами, а також із громадськістю об'єднуються в кредитні союзи. Таким є, наприклад, Федеральний союз німецьких банків. Його співпраця з державними органами контролю особливо тісна при видачі ліцензій на право займатися банківською діяльністю та при організації системи страхування депозитів. Завдяки такій співпраці грошові кошти на рахунках клієнтів банків зберігаються практично в повному обсязі.

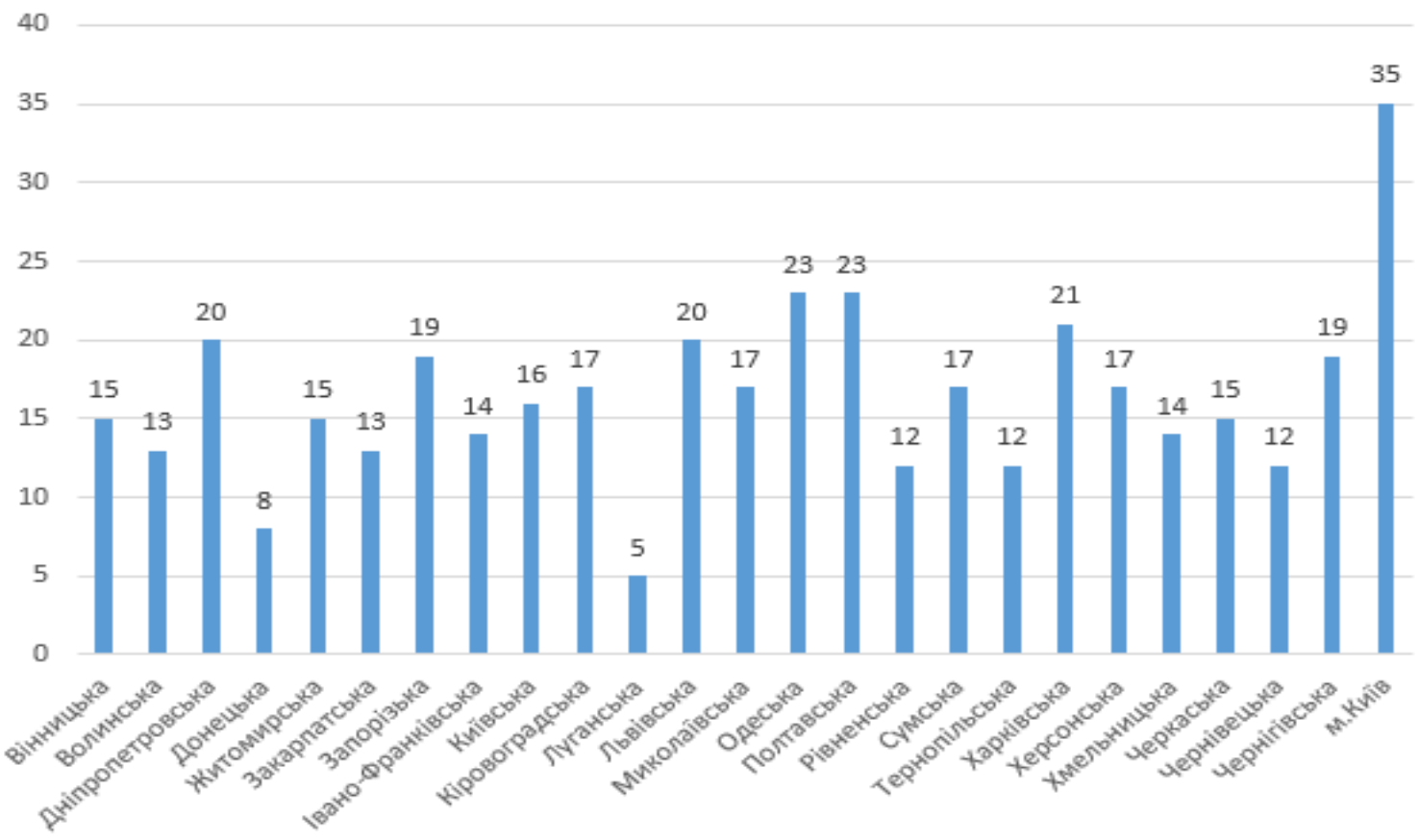

Рис. 1. Кількість структурних підрозділів банків в областях України в розрахунку на 100 тис. осіб наявного населення, станом на 01.01.2021 p.

Джерело: сформовано автором за даними офіційних сайтів НБУ та Держслужби статистики України.

Згідно із законом «Про банки і банківську діяльність» від 07.12.2000 № 2121-III (ст. 9-13), в Україні, як і в інших країнах, банки мають право створювати банківські об'єднання. Ці об'єднання можуть належати до таких типів: 1) банківська корпорація; 2) банківська холдингова група; 3) фінансова холдингова група. Першим офіційно зареєстрованим банківським об’єднанням в 
Україні стала (у 2008 р.) «Банківська холдингова група «Сведбанк Фінанси». До нього увійшли: ВАТ «Сведбанк» (материнська банківська установа) та ЗАТ «Сведбанк Інвест» (як банк-учасник). Об'єднання було створено для реалізації стратегії стабільного розвитку учасників об'єднання та підвищення якості надання банківських послуг. Однак це об'єднання проіснувало недовго, тому що Swedbank у 2012 р. пішов 3 ринку України. Наразі найбільш дієвою є Асоціація українських банків. Натомість асоціації та банківські союзи регіонального рівня, що об'єднують незначну кількість учасників, не вирізняються конкретними і вагомими напрямами діяльності [10, с. 49].

У розвинених країнах банки є дуже важливими учасниками фінансово-промислових груп (ФПГ). Механізм їх утворення на основі фінансового капіталу, що виникає при злитті банківського i промислового капіталів, розкрив ще Р. Гільфердінг у праці «Фінансовий капітал» (1910). В Україні перші ФПГ виникли в середині 1990-х рр. Для упорядкування їх становленння і функціонування 21 листопада 1995 р. було прийнято закон «Про промислово-фінансові групи» (ПФГ). Згідно закону, ПФГ мали стати «локомотивом» виконання державних програм розвитку пріоритетних галузей виробництва та структурної перебудови національної економіки. Однак процес створення та діяльності ПФГ в Україні пішов не за сценарієм, що був визначений законом, а за сценарієм задоволення інтересів олігархічних груп. Згідно з ним, ПФГ не набували власної правосуб’ єктності і це дозволяло їм безконтрольно виводити фінансові ресурси зі сфери виробництва у сферу обігу, де швидкість обороту капіталу є більшою, та приховувати доходи й виводити їх в офшори. Тому й не дивно, що єдина офіційно створена постановою Кабінету Міністрів України (КМУ) від 16 травня 2001 р. ПФГ «Титан» була розформована за постановою КМУ від 28 жовтня 2004 р., а чинність закону «Про ПФГ в Україні» взагалі було скасовано 2 жовтня 2010 р. Однак це не означає, що в Україні немає ПФГ чи ФПГ. «Фактичні» ФПГ є і в назві багатьох із них навіть фігурує термін «група», так, наприклад, називається група ТАС. Проте більшість ФПГ «шифрується» під різні корпоративні структури асоціації, холдинги, концерни, консорціуми, як, наприклад, Development Construction Holding (DCH) - під холдинг. Але головне не це, а те, що українські ФПГ і банки у їх складі, на жаль, так і не стали «локомотивами» національної економіки, як це має місце в США, Японії, Німеччині, Південній Кореї та інших розвинених країнах.

Що стосується небанківських фінансових установ, то чимало 3 них працюють в Україні в умовах низького рівня прозорості та фрагментарності інформації щодо своєї діяльності, що часто дезорієнтує їх клієнтів, партнерів і контролюючих органів. Однак, ситуацію має дещо поліпшити перехід цих установ 31 липня 2020 р. з-під наглядової «парасольки» Нацкомфінпослуг, яка була ліквідована, до сфери «опіки» двох інших органів - НБУ та Національної комісії 3 цінних паперів і фондового ринку (НКЦПФР). І це дає надію на те, що деякі з них, зокрема приватні пенсійні фонди та кредитні спілки, в майбутньому відіграватимуть, як показує досвід США та Великої Британії, помітну роль у фінансуванні інвестиційного розвитку суб'єктів підприємництва.

Інституційне забезпечення банківської системи, окрім НБУ і НКЦПФР, формують також інші інститути й інституції, зокрема Фонд гарантування вкладів фізичних осіб (ФГВФО), Рада 3 фінансової стабільності, низка законодаавчих актів.

ФГВФО був заснований Указом Президента України «Про заходи щодо захисту прав фізичних осіб - вкладників комерційних банків» від 10.09.1998 № 996/98. Необхідність його створення для захисту прав та законних інтересів вкладників банків стала очевидною на тлі світової фінансової кризи 1998 р., наслідком якої стало майже подвійне зниження курсу гривні до долара США.

Важливою інституцією із регулювання діяльності банківської системи України стала Рада 3 фінансової стабільності, що була створена в 2015 р. До їі складу увійшли керівники НБУ, Мінфіну, НКЦПФР, Нацкомфінпослуг (нині ліквідованої) та ФГВФО. На неї покладена функція із забезпечення своєчасного виявлення і мінімізації ризиків, що загрожують стабільності банківської та фінансової системи держави. Щоправда, реалізувати цю функцію повною мірою вона не має можливості, оскільки її рішення мають рекомендаційний характер [3, с. 159].

Якість інституційного регулювання банківської системи України щонайбільше визначає низка законодавчих актів, головними $з$ яких є Конституція України, Господарський кодекс та закони «Про Національний банк України» i «Про банки і банківську діяльність». Слід, однак, зауважити, що далеко не всі спірні питання організації банківської системи та банківської діяльності належним 
чином у них виписані, наприклад щодо націоналізації та денаціоналізації комерційних банків. I щоб виправити ситуацію недостатньо прийняття підзаконних актів. Необхідним $\epsilon$ або прийняття нових законів або законів на зміну чи в доповнення до існуючих та ще й таких, які б орієнтували на кращі міжнародні практики із банківської справи та міжнародні норми, зокрема вимоги Базельського комітету з банківського нагляду. Одним із таких законів мав стати Закон України «Про внесення змін до деяких законодавчих актів України щодо удосконалення механізмів регулювання банківської діяльності» від 13.05.2000 № 590-IX, в якому оновлено механізми виведення банків з ринку за участю держави. Однак він був написаний під «диктовку» МВФ і «протягнутий» у Верховній Раді України аби створити перепони для відновлення діяльності (за рішенням судів) ряду виведених 3 ринку банків та денаціоналізації Приватбанку. Зрозуміло, що законодавство в плані регулювання банківської діяльності треба удосконалювати, але не таким чином, щоб норми спеціального закону відміняли рішення судів. Якщо ж рішення судів у сфері банківської діяльності й були протизаконними, то це треба вирішувати шляхом удосконалення роботи судів і реформування судової гілки влади, а не шляхом виведення банків із під рішень судів загальної юрисдикції.

Звичайно, вирішення багатьох проблем організації банківської системи України залежатиме від того, наскільки високорганізованим елементом стане у ній НБУ як її центральний банк.

Головною функцією НБУ (і це записано в ст. 99 Конституції України та в ст. 6 Закону України «Про Національний банк України»), як і більшості центробанків, $\epsilon$ забезпечення стабільності національної грошової одиниці. На жаль, із цією функцією, особливо в періоди криз, НБУ далеко не завжди справлявся. Залишається багато запитань і щодо виконання ним функції регулятора грошовокредитних ринків (зокрема щодо видачі та відкликання ліцензій комерційних банків) і як головного розрахункового центру банківської системи та системної резервної установи. Натомість НБУ обзавівся невластивими для більшості центробанків функціями, пов'язаних із рятуванням i ліквідацією збанкрутілих комерційних банків та розпорядження їх капіталом і правами власності. Це не означає, що НБУ має обмежитись вузьким колом функцій, він їх може розширити, але вони мають гармонійно поєднуватися із його основними функціями.

Позитивним прикладом у цьому відношенні може слугувати Банк Франції. Він, окрім основних функцій (емісійної та депозитно-позикової) виконує ще й ряд додаткових - із ведення поточних рахунків приватних осіб, проведення операцій з цінними паперами, надання консалтингових послуг підприємствам. Для виконання такого широкого спектру функцій сформувано систему інформаційних служб, які оперують найширшими та найточнішими даними про учасників фінансового ринку, реального сектора економіки та сфери послуг. Але, володіючи цією інформацією, Банк Франції водночас значну увагу приділяє дотриманню комерційної таємниці та нейтральної позиції щодо різних сфер бізнесу, тобто виконує ще й важливу функцію із захисту конфіденційної фінансової інформації [5, с. 42].

Звичайно, під уточнені функції НБУ має бути підведена і його удосконалена організаційна структура включно з повноваженнями посадових осіб. I законодавче регульовання мало б цьому сприяти, однак на практиці цього не спостерігається. Так, норми закону про НБУ, за якими його Рада розробляє Основні засади грошово-кредитної політики, а Голова НБУ при цьому не очолює Раду, $\epsilon$ недосконалою. В такому разі Голова НБУ не може одноосібно нести відповідальність за реалізацію цієї політики, як це практикується в більшості зарубіжних центробанків. У Європейському центральному банку (ЄЦБ), наприклад, його Голова (Президент) очолює як Раду - орган, що визначає грошово-кредитну політику країн єврозони, так і його виконавчий орган. Виправити цей та інші недоліки в організаційній структурі НБУ заважає фактор заполітизованості призначень складу Ради НБУ з числа представників глави держави та олігархічного лобі. Бажано, щоб вона складалася 3 незалежних фахівців, і це дозволило б НБУ стати по-справжньому незалежною інституцією.

Для підвищення інституційної спроможності НБУ, необхідної для подолання кризових явищ у грошово-кредитній системі, наприкінці 2014 р. у ньому було створено Комітет з монетарної політики - консультативний орган у складі Голови НБУ, його заступника (на якого покладено загальне керівництво процесами формулювання принципів грошово-кредитної політики та монетарної стабільності) та ряду членів за посадою. До речі, діяльність аналогічних комітетів у складі центробанків Великобританії та Канади уже добре себе зарекомендувала [11, с. 181-182]. У тому ж 
році було створено й Громадську раду - постійно діючий колегіальний консультативно-дорадчий орган для налагодження ефективної взаємодії НБУ з громадськістю, зокрема для забезпечення стабільності банківської системи, захисту прав та інтересів споживачів банківських послуг та надання пропозицій щодо вдосконалення законодавства України у фінансовій сфері [3, с. 159].

Організаційні зміни торкнулися й територіальної структури НБУ: замість 25 його територіальних управлінь, що функціонували в кожній області країни, було створено чотири його представництва у макрорегіонах із центрами у Києві, Львові, Одесі та Дніпрі. Це дозволило скоротити чисельність персоналу в системі НБУ та витрати на заробітну плату й утримання будівель [3, c. 159].

Наразі належить визначитися щодо необхідності формування і розміру статутного капіталу НБУ. Саме формування статутного капіталу у ньому як у центробанку - це, швидше, традиція копіювання фінансової моделі комерційного банку, тобто структури з приватною формою власності, хоча НБУ, згідно ст. 3 відповідного закону, є державним. До речі, більшість центробанків у світі також є державними - це, зокрема, центробанки Німеччини, Великої Британії, Франції, Іспанії та Нідерландів. У деяких країнах, наприклад Японії, держава володіє лише частиною капіталу центробанку, а 45 \% капіталу Банку Японії належить приватним та інституційним акціонерам. У США акціонерами ФРС є тільки комерційні банки. Проте навіть за такої форми власності центробанку держава відіграє головну роль у формуванні органів його управління та у визначенні грошово-кредитної політики країни.

У різних країнах світу центральні банки мають різний капітал (в абсолютному і відносному відношенні до суми пасивів або по відношенню до ВВП). Так, у ФРС США величина резервного капіталу підтримується на рівні до 100 \% від величини уставного капіталу. Хоча досвід ряду країн показує, що центральні банки можуть проводити ефективну грошово-кредитну політику навіть за умови від'ємного капіталу [12, с. 2200-2201].

Розмір статутного капіталу НБУ невеликий і складає всього 10 млн. грн. Щоправда, за рішенням Ради НБУ він може бути збільшений. Джерелами формування статутного капіталу НБУ є частина його прибутку до розподілу, а при необхідності - Державний бюджет України. Офіційні резервні активи НБУ включають не тільки його статутний капітал, але й резерви в іноземній валюті, резервну позицію в МВФ, спеціальні права запозичення, золото та інші резервні активи, що $є$ у його розпорядженні. Головним джерелом ризику для активів НБУ є кредити уряду та державні цінні папери, зокрема облігації внутрішньої державної позики (ОВДП).

НБУ як центральний банк апріорі не може бути неплатоплатоспроможним, тому що він $\epsilon$ емісійним банком, що монопольно випускає законні засоби платежу. Це означає, що в разі необхідності він може на законних підставах використати чергову емісію для погашенні свого боргу. 3 цього випливає, що центробанк необов'язково повинен мати статутний капітал. I це вимагає перегляду теоретичних уявлень щодо сутності та ролі капіталу центрального (емісійного) банку у грошово-кредитній системі країни [12, с. 2200-2201].

У сучасних умовах вважається, що центральний банк може проводити ефективну грошовокредитну політику лише за умови його незалежності від органів виконавчої влади. Так, у Німеччині Бундесбанк не підпорядковується ні Уряду, ні Парламенту, ні Вищому Суду, а діє лише на засадах закону про Бундесбанк [5, с. 42].

Незалежність НБУ, як і Бундесбанку, необхідна для того, щоб він міг виступати опонентом уряду, який в окремі періоди може керуватися суто політичними міркуваннями, наприклад майбутніми виборами, або ж мати іншу позицію щодо вирішення тих чи інших економічних, зокрема фінансових, проблем, наприклад щодо пощуку шляхів зниження рівня безробіття та визначення додаткових джерел фінансування бюджету.

На думку Ф. Хайєка та Б. Клайна, незалежність центрального банку особливо важлива для досягнення стабільності грошової одиниці $[13$, с. 5]. Натомість фундатор монетаризму М. Фрідман вважав, що центральні банки неспроможні істотно впливати на такі кінцеві цілі, як зниження темпів інфляції, зростання ВВП та зайнятості; їх вплив є суттєвим лише в плані досягнення проміжних цілей - низьких процентних ставок та оптимальної структури грошових агрегатів [14, с. 160]. Деякі 
вчекні пішли в цьому плані ще далі. Так, В. Козюк на основі аналізу даних в розрізі 150 країн довів, що між інфляцією й незалежністю центробанків зберігається обернений зв'язок [15, с. 9].

Навіть за умов неповної незалежності НБУ його грошово-кредитна політика далеко не завжди відповідає політиці, яку проводять фінансові органи країни, зокрема міністерство фінансів, щодо динаміки цін, підтримання валютного курсу, випуску ОВДП тощо. Це вносить дисонанс у підходах до вирішення важливих питань грошовао-кредитної політики, а тому потребує їх узгодження. У зв'язку з цим варто зауважити, що центробанки зарубіжних країн, хоча й переважно є незалежними інституціями, однак тією чи іншою мірою координують свою діяльність із урядами своїх країн, зокрема міністерством фінансів. У деяких країнах, зокрема США, ця координація є достатньо слабкою, наприклад щодо відсоткової політики, і це гальмує розвиток економіки країни. Натомість у Японії співпраця між урядом і центральним банком $є$ важливою складовою «абеноміки» економічної політики, яку довгий час проводив, будучи прем'єр-міністр країни, Сіндзо Абе. Там Банк Японії кожні 6 місяців (за посередництва міністра фінансів) звітує перед парламентом про реалізацію грошово-кредитної політики країни [6, с. 96]. Крім того, в законодавстві Японії передбачено суворе право державних органів на скасування рішень центрального банку [16, с. 125].

На жаль, рівень довіри українського суспільства до діяльності НБУ, особливо після епохи правління В. Гонтарєвої і $\mathrm{K}^{0}$, ще більше знизився. I щоб його суттєво підвищити, необхідно самим ретельним чином провести аудит руху активів НБУ на предмет можливих зловживань його керівництва, на які, зокрема вказав С. Тарута (виведення «Дельта Банком» коштів рефінансування на загальну суму близько 10 млрд. грн., 3 яких 4,1 млрд грн, було конвертовано в 535,3 млн. дол. у Прибалтику) [16, с. 13]. Нам дуже важко збагнути, як такі оборудки могли відбутися без відома Голови та інших відповідальних працівників НБУ. Але незалежно від результатів розслідування слід дотримуватись сучасних вимог до рівня прозорості грошово-кредитної політики та дій НБУ як центробанку. Ці вимоги були викладені МВФ у 1999 р. в «Кодексі належної практики із забезпечення прозорості в грошово-кредитній і фінансовій політиці: декларація принципів» [17]. Відповідно до цього документа, рішення з цієї політики (насамперед центрального банку) мають надавати суспільству на принципах зрозумілості, доступності та своєчасності. I, звичайно, відповідна інформація має бути щонайповніше висвітлена у ЗМІ. Одним із взірцевих в цьому плані є ЄЦБ. Ширина i глибина інформаційного наповнення його офіційного сайту в мережі Інтернет $\epsilon$ унікальною. Об'єктивності ради варто відмітити, що масив статистичних даних і аналітичних матеріалів, які наведені на сайті НБУ, щодо його процентної політики, емісії грошей, інфляції, ліквідності банківської системи, норм обов'язкових резервів, валютного курсу гривні $є$ достатнім для того, щоб дати об'єктивну оцінку діяльності самого НБУ та інших установ банківської системи й загалом фінансового ринку країни.

Висновки. Проведене дослідження показало, що процес формування банківської системи України, як і в більшості країн, був складним і тривалим. У його ході нагромадилось чимало різних проблем, в т. ч. й організаційного плану, які потребують свого вирішення із врахуванням зарубіжного досвіду. Важливою проблемою організаційної структури банківської системи України $є$ те, що в ній недостатньо або й зовсім не представлені такі види спеціалізованих банків, як земельні та кооперативні, хоча вони добре зарекомендували себе у Німеччині, Італії, США та інших країнах, зокрема в плані розвитку малого й середнього бізнесу та сільських територій. Чітко виражена тенденція до зростання в Україні частки універсальних банків, як це показали дослідження міжнародних наукових організацій, не відповідає критеріям підвищення ефективності їх функціонування. Відтак, для зменшення ризиків їх діяльності та підвищення дохідності вони мають розвиватися шляхом галузевої спеціалізації та географічної диверсифікації. Цьому в Україні частково заважають диспропорції в регіональному розподілі банків та їх структурних підрозділів. Значні перспективи розвитку банківської системи в Україні, як і у всьому світі, пов’язуються 3 Інтернет-банкінгом. А для активізації економічної діяльності в Україні, зокрема прискорення неоіндустріалізації, доцільним є створення окремого банку розвитку.

В Україні, на відміну більшості розвинених країн, зокрема Франції, банки мають обмежене членство в різних спілках та асоціаціях, і це не приносить бажаного синергічного ефекту та утруднює контроль за їх діяльністю. Банки в Україні також не є (офіційно) учасниками фінансово- 
промислових груп, а відтак, не відіграють належної ролі в розвитку національної економіки. А небанківські фінансові установи, зокрема приватні пенсійні фонди та кредитні спілки, працюють у неповну силу й недостатньо прозоро, хоча в перспективі можуть мати важливе значення, як це показує досвід США та Великобританії, у фінансуванні розвитку підприємництва. У вирішенні ряду проблем організації банківської системи України більшу роль мають відігравати численні інститути й інституції, зокрема законодавчі акти, Фонд гарантування вкладів фізичних осіб, Рада $з$ фінансової стабільності та ін.

Вирішення багатьох проблем організації банківської системи України залежатиме від того, наскільки високорганізованим елементом у ній стане НБУ як іiі центральний банк. Для цього необхідно: переглянути його фукції (із врахуванням досвіду Банку Франції); підвести під скориговані функції нову організаційну структуру, в т. ч й територіальну; активізувати роботу Комітету з монетарної політики (на основі досвіду Великобританії та Канади); чітко визначитися 3 резервними активами, незалежністю та формами взаємодії із урядом (із врахуванням досвіду Японії та інших країн); підвищити прозорість діяльності (на основі розслідування можливих зловживань керівництва, врахування вимог МВФ та широкого оприлюднення результатів діяльності).

\section{Джерела та література}

1. Розвиток банківської системи України : монографія; ДУ «Ін-т економіки та прогнозування» НАН України. Київ, 2008. 581 с.

2. Горох О. В. Проблеми розвитку банківської системи в Україні та шляхи їх подолання. Вісник ХНАУ. Серія : Економічні науки. 2014. № 7. С. 231-237.

3. Далгич К. В. Проблеми, тенденції та напрями вдосконалення інституційного розвитку банківської системи України. Вчені записки Таврійського національного університету імені В. I. Вернадського. Серія : Економіка і управління. 2018. Т. 29, № 3. С. 158-164.

4. Дзюблюк О. В. Актуальні проблеми розвитку банківської системи України. Банківська справа. 2016. № 1. С. 3-32.

5. Кашпрук Ю. А. Реформування системи інституційного регулювання банківської діяльності в Україні у контексті світового досвіду. Держава та регіони. Серія : Економіка та підприємнищтво. 2013. № 1. С. 41-44.

6. Побережна Н. М., Колесніченко А. С. Зарубіжний досвід грошово-кредитної політики та особливості застосування деяких аспектів банківської системи в Україні. Науковий вісник Ужгородського університету. Серія : Економіка. 2014. Вип. 2. С. 92-97.

7. Фімяр С. В. Особливості функціонування кредитної системи України: міжнародні порівняння. Вісник Черкаського університету. Серія : Економічні науки. 2015. № 33. С. 122-126.

8. Котуранова Т. В., Вартоха Я. С. Александрова М. О. Інтернет-банкінг в Україні - інноваційний розвиток банківської сфери. Економічний простір. 2019. № 146. С. 43-56.

9. Кіндзерський Ю. До питання створення і забезпечення дієвості Банку Розвитку в Україні. Економіст. 2011. № 5. С. 65-69.

10. Прицюк Л. А. Аналіз діяльності банківських об'єднань, створених на некомерційних засадах. Міжнародний науковий журнал «Інтернаука». Серія : Економічні науки. 2018. № 2. С. 46-51.

11. Дудченко В. Ю. Незалежність центральних банків: світові тенденції. Науковий вісник Полісся. 2019. № 2 (18). С. 177-183.

12. Сухарев А. Н. Капитал центрального банка: сущность, формирование и проблема достаточности. Финансы и кредит. 2017. Т. 23, № 37. С. 2198-2207. URL: https://cyberleninka.ru/article/n/kapital-tsentralnogobanka-suschnost-formirovanie-i-problema-dostatochnosti/viewer

13. Сліпченко Т. О. Гносеологічні засади побудови механізму монетарного регулювання. Науковий вісник Чернівецького університету. Економіка. 2015. Вип. 750. С. 3-8.

14. Фридман М. Если бы деньги заговорили / пер. англ. Москва : Дело, 1998. 160 с.

15. Козюк В. В. Незалежність центробанків та інфляція: фрагментаризація суспільства vs верховенство права. Фінанси Украӥни. 2019. № 3. С. 7-21.

16. Тарута С. Гонтарева. Загроза економічній безпеці України : Незалежна доповідь. Київ : Асоціація банків України, 2016. 22 c. URL : http://www.hai-nyzhnyk.in.ua/downloads/2016.hontareva.pdf

17. Косова Т. Д., Ангеліна I. А. Кодекс фіскальної прозорості: ініціативи МВФ. Економічний вісник Донбасу. 2014. № 3. С. 77-81. 


\section{References}

1. Baranovskyi, O. I., etc. (2008). Rozvytok bankivskoi systemy Ukrainy: monohrafiia [Development of the banking system of Ukraine: monograph]; Institute of Economics and Forecasting, National Academy of Sciences of Ukraine. Kyiv, 581 p. [in Ukrainian].

2. Horokh, O. V. (2014). Problemy rozvytku bankivskoi systemy v Ukraini ta shliakhy yikh podolannia [Problems of development of the banking system in Ukraine and ways to overcome them]. Visnyk KhNAU. Seriia: Ekonomichni nauky - Bulletin of KhNAU. Series: Economic Science, 7, 231-237 [in Ukrainian].

3. Dalhych, K. V. (2018). Problemy, tendentsii ta napriamy vdoskonalennia instytutsiinoho rozvytku bankivskoi systemy Ukrainy [Problems, trends and directions of improving the institutional development of the banking system of Ukraine]. Vcheni zapysky Tavriiskoho natsionalnoho universytetu imeni V. I. Vernadskoho. Seriia: Ekonomika i upravlinnia - Scientific notes of Tavriya National University named after V. I .Vernadsky. Series: Economics and Management, 29(3),158-164 [in Ukrainian].

4. Dziubliuk, O. V. (2016). Aktualni problemy rozvytku bankivskoi systemy Ukrainy [Actual problems of development of the banking system of Ukraine]. Bankivska sprava - Banking, 1, 3-32 [in Ukrainian].

5. Kashpruk Yu. A. (2013). Reformuvannia systemy instytutsiinoho rehuliuvannia bankivskoi diialnosti v Ukraini u konteksti svitovoho dosvidu [Reforming the system of institutional regulation of banking in Ukraine in the context of world experience]. Derzhava ta rehiony. Seriia: Ekonomika ta pidpryiemnytstvo - State and regions. Series: Economics and Entrepreneurship, 1, 41-44 [in Ukrainian].

6. Poberezhna, N. M., Kolesnichenko, A. S. (2014). Zarubizhnyi dosvid hroshovo-kredytnoi polityky ta osoblyvosti zastosuvannia deiakykh aspektiv bankivskoi systemy v Ukraini [Foreign experience of monetary policy and features of application of some aspects of the banking system in Ukraine]. Naukovyi visnyk Uzhhorodskoho universytetu. Seriia : Ekonomika - Scientific Bulletin of Uzhhorod University. Series: Economics, 2, 92-97 [in Ukrainian].

7. Fimiar, S. V. (2015). Osoblyvosti funktsionuvannia kredytnoi systemy Ukrainy: mizhnarodni porivniannia [Features of the credit system of Ukraine: international comparisons]. Visnyk Cherkaskoho universytetu. Seriia : Ekonomichni nauky - Bulletin of Cherkasy University. Series: Economic Sciences, 33, 122-126 [in Ukrainian].

8. Koturanova, T. V., Vartokha, Ya. S. Aleksandrova, M. O. (2019). Internet-bankinh v Ukraini - innovatsiinyi rozvytok bankivskoi sfery [Internet banking in Ukraine - innovative development of the banking sector]. Ekonomichnyi prostir-Economic space, 146, 43-56 [in Ukrainian].

9. Kindzerskyi, Yu. (2011). Do pytannia stvorennia i zabezpechennia diievosti Banku Rozvytku v Ukraini [On the issue of creating and ensuring the effectiveness of the Development Bank in Ukraine]. Ekonomist - Economist, 5 , 65-69 [in Ukrainian].

10. Prytsiuk, L. A. (2018). Analiz diialnosti bankivskykh obiednan, stvorenykh na nekomertsiinykh zasadakh [Analysis of the activities of banking associations established on a non-profit basis]. Mizhnarodnyi naukovyi zhurnal "Internauka». Seriia: Ekonomichni nauky - International scientific journal "Internauka". Series: Economic Science, 2 , 46-51 [in Ukrainian].

11. Dudchenko, V. Yu. (2019). Nezalezhnist tsentralnykh bankiv: svitovi tendentsii [Independence of central banks: global trends]. Naukovyi visnyk Polissia - Scientific Bulletin of Polissya, 2(18), 177-183 [in Ukrainian].

12. Sukharev, A. N. (2017). Kapital czentralnogo banka: sushhnost, formirovanie i problema dostatochnosti [Capital of the central bank: the essence, formation and problem of sufficiency]. Finansy $i$ kredit - Finance and credit, 23(370, 2198-2207. Retrieved from: https://cyberleninka.ru/article/n/kapital-tsentralnogo-banka-suschnostformirovanie-i-problema-dostatochnosti/viewer [in Russian].

13. Slipchenk, T. O. (2015). Hnoseolohichni zasady pobudovy mekhanizmu monetarnoho rehuliuvannia [Epistemological principles of construction of the mechanism of monetary regulation]. Naukovyi visnyk Chernivetskoho universytetu. Ekonomika - Scientific Bulletin of Chernivtsi University. Economy, 750, 3-8 [in Ukrainian].

14. Fridman, M. (1998). Esli by dengi zagovorili [If money started talking]. Moscow: Delo. 160 p. [in Russian].

15. Koziuk, V. V. (2019). Nezalezhnist tsentrobankiv ta infliatsiia: frahmentaryzatsiia suspilstva vs verkhovenstvo prava [Independence of central banks and inflation: fragmentation of society vs the rule of law]. Finansy Ukrainy Finance of Ukraine, 3, 7-21 [in Ukrainian].

16. Taruta, S. (2016). Hontareva. Zahroza ekonomichnii bezpetsi Ukrainy: Nezalezhna dopovid Gontareva. [Threat to Ukraines economic security: An independent report]. Kyiv: Association of Banks of Ukrain. 22 p. Retrieved from:: http://www.hai-nyzhnyk.in.ua/downloads/2016.hontareva.pdf [in Ukrainian].

17. Kosova, T. D., Anhelina I. A. (2014)/ Kodeks fiskalnoi prozorosti: initsiatyvy MVF [Angelina IA Code of Fiscal Transparency: IMF initiatives]. Ekonomichnyi visnyk Donbasu - Economic Bulletin of Donbass, 3, 77-81 [in Ukrainian]. 